Revista de Biología Marina y Oceanografía

Vol. 49, №3: 577-587, diciembre 2014

DOI 10.4067/S0718-19572014000300014

\title{
ReseARCH Note \\ Unarmored dinoflagellates present during a bloom of Ceratoperidinium falcatum in Bahía de La Paz, Gulf of California
}

\author{
Dinoflagelados desnudos presentes durante un florecimiento de Ceratoperidinium falcatum \\ en Bahía de La Paz, Golfo de California

\section{Ismael Gárate-Lizárraga ${ }^{1}$}

\begin{abstract}
${ }^{1}$ Instituto Politécnico Nacional, Centro Interdisciplinario de Ciencias Marinas, Departamento de Plancton y Ecología Marina, Apartado postal 592, La Paz, B.C.S. 23000, México. igarate@ipn.mx

Abstract.- During a sampling on 16-17 January 2013 in the southwest part of Bahía de La Paz, a moderate bloom of the dinoflagellate Ceratoperidinium falcatum was detected. Its abundance varied from 11,200 to 145,400 cells L $^{-1}$ during this period in seawater temperature at $23^{\circ} \mathrm{C}$ and salinity of 35.42 . The specimens were solitary cells. Few two-celled chains were observed. Young cells were relatively small, 30-70 $\mu \mathrm{m}$ long; 17-36 $\mu \mathrm{m}$ wide, from ovately elongate to fusiform. Mature individuals were 40-190 $\mu \mathrm{m}$ long and 20-36 $\mu \mathrm{m}$ wide. Including C. falcatum, 21 species belonging to 5 orders of unarmored dinoflagellates were identified during this bloom. Four species are new records for the Gulf of California and three are new records for the Pacific coast of Mexico.
\end{abstract}

Key words: Unarmored dinoflagellates, proliferation, Ceratoperidinium falcatum, Gulf of California

\section{INTRODUCTION}

Microalgae proliferations are frequent and periodic throughout the year in Bahía de La Paz in the southwestern part of the Gulf of California (Gárate-Lizárraga et al. 2001, 2006). The majority of red tides along both coast zones of the gulf have been produced by dinoflagellate species (Cortés-Altamirano 2002, Gárate-Lizárraga et al. 2001, 2006) and proliferations of naked dinoflagellates are common (Cortés-Altamirano 2002, Gárate-Lizárraga et al. 2004a). Noctiluca scintillans, Gymnodinium catenatum, Gyrodinium instriatum, Cochlodinium polykrikoides, $C$. fulvescens, Katodinium glaucum and Amphidinium carterae are the most common blooming species recorded in Bahía de La Paz (Gárate-Lizárraga 2012, Gárate-Lizárraga et al. 2001, 2004a, 2006, 2009).

The unarmored dinoflagellates comprise several orders which lack cellulose plates, but have a membranous outer covering of small vesicles (Hallegraeff et al. 2010). Main unarmored dinoflagellates orders reported in Bahía de La Paz are: Gymnodiniales, Brachidiniales, Noctilucales and Actiniscales. Most studies of Gymnodiniales have been focused on the species responsible for harmful algal blooms, which are abundant in coastal waters of the Gulf of California (Cortés-Altamirano 2002, Gárate-Lizárraga et al. 2001, 2009; Gárate-Lizárraga 2012, 2014). This report describes the first proliferation of Ceratoperidinium falcatum (Kofoid et Swezy) Reñé et de Salas in Bahía de
La Paz. Composition of naked dinoflagellate species during this proliferation is given.

\section{MATERIALS AND METHODS}

Bahía de La Paz is the largest bay on the east side of Baja California Peninsula. The bay constantly exchanges water with the Gulf of California through a wide northern and a southern opening (Gómez-Valdés et al. 2003). The main northern channel is wide and deep (up to $300 \mathrm{~m}$ ), while the southern mouth is shallow and associated with a shallow basin about $10 \mathrm{~m}$ deep. There is a shallow lagoon, the Ensenada of La Paz, connected to the bay by a narrow inlet (1.2 km wide) with an average depth of $7 \mathrm{~m}$. As part of a continuing toxic or noxious microalgae monitoring program, phytoplankton bottle samples were collected monthly at one fixed sampling station in the bay (Fig. 1; station $1,24^{\circ} 21^{\prime} \mathrm{N}, 110^{\circ} 31^{\prime} \mathrm{W}$ ) and another one in the mouth of the lagoon (Fig. 1; station $2,24.23^{\circ} \mathrm{N} ; 110.34^{\circ} \mathrm{W}$ ). Phytoplankton samples were collected into plastic flasks, fixed with Lugol's solution and later preserved with $4 \%$ formalin. Identification and cell counts were made in $5 \mathrm{ml}$ settling chambers and the cells were studied under an inverted Carl Zeiss phase-contrast microscope (Utermöhl 1958). Both surface and vertical tows from $15 \mathrm{~m}$ depth were made with a phytoplankton $20 \mu \mathrm{m}$ mesh net. A portion of each sample was immediately fixed with acid 


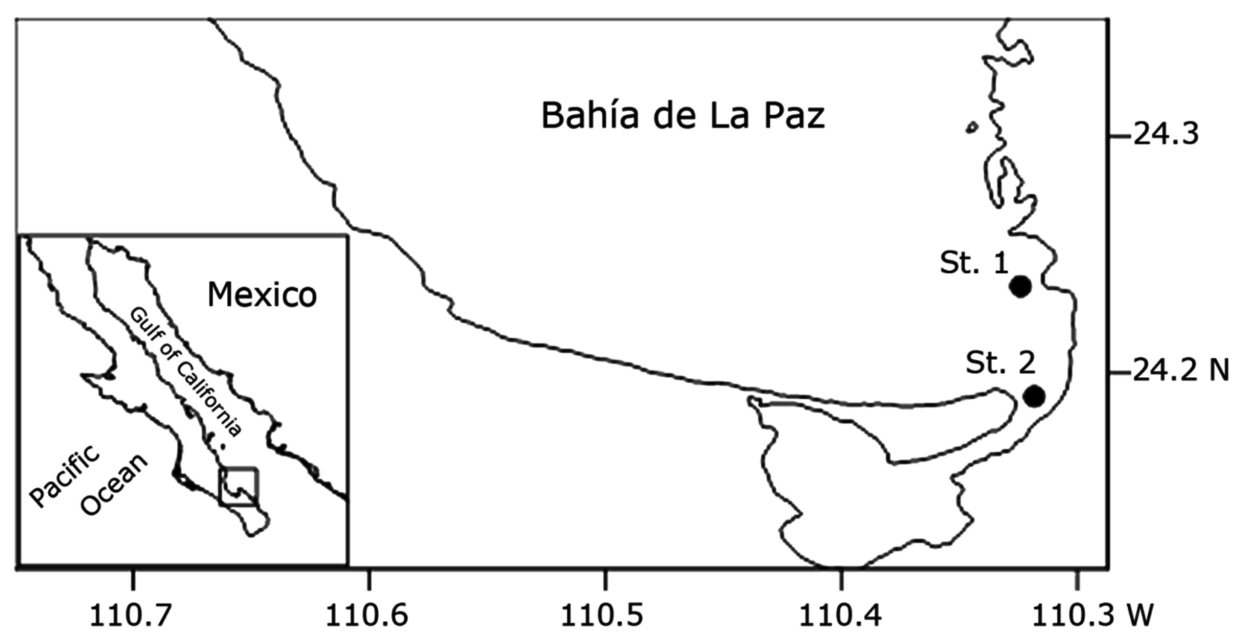

Figure 1. Map of the study area indicating sampling stations for microalgae monitoring in Bahía de La Paz / Mapa del área de estudio indicando las estaciones de monitoreo de microalgas en la Bahía de La Paz

Lugol's solution and later preserved in $4 \%$ formalin. Live phytoplankton samples were used to properly identify some uncommon species also found in the bottle samples. Sea surface temperature was measured with a bucket thermometer (Kahlsico International, El Cajon, CA, USA). Salinity was measured with a refractometer (Model STX3, Vee Gee Scientific, Kirkland, WA). An Olympus CH2 compound microscope was used to measure cells. A digital Konus camera (8.1 MP) recorded images.

\section{RESULTS AND DISCUSSION}

Ceratoperidinium falcatum was the main responsible species in the proliferation detected at the mouth of Bahía de La Paz on 16-17 January 2013. Seawater temperature was $23^{\circ} \mathrm{C}$ and salinity was 35.42 . The specimens were solitary cells (Figs. 2A-L). Few two-celled chains were observed. Young cells were solitary, relatively small, 30$70 \mu \mathrm{m}$ long, 17-36 $\mu \mathrm{m}$ wide, from ovately elongate to fusiform (Figs. 2A-D). Mature individuals were 40-190 $\mu \mathrm{m}$ long and 20-36 $\mu \mathrm{m}$ wide $(\mathrm{n}=30)$. Some mature specimens had 'article cells' (Figs. 2J-K), which are more differentiated and the apex is thickened, matching those observed by Konovalova (2003). It is likely that these 'cells' bear generative functions of the mother sporont organism (Konovalova 2003). These 'article cells' can be observed in live specimens, (Fig. 2J) but also in fixed cells (Figs. 2K-L). Retractile appendices (both apical and antapical) are present at least during some life-cycle stages (Figs. 2G-L). According to Konovalova (2003), $C$. falcatum has about 9 developmental stages in its life cycle. Five life stages were observed during this event (Figs. 2A-L), coinciding with Konovalova (2003) and also reported by Gárate-Lizárraga et al. (2010) in Bahía de La Paz.

Unarmored dinoflagellates abundance varied from 29,000 to 193,000 cells $\mathrm{L}^{-1}$. Abundances of $C$. falcatum during this event were moderate $(11,200-145,400$ cells $\left.\mathrm{L}^{-1}\right)$. Gárate-Lizárraga et al. (2009) reported C. falcatum in Bahía de La Paz ranging from 1000-2000 cells L ${ }^{-1}$. AlonsoRodríguez et al. (2010) reported very low densities of $C$. falcatum: 603 cells $\mathrm{L}^{-1}$ from Islas Marietas and 1672 cells $\mathrm{L}^{-1}$ in Bahía Banderas. This species is well distributed along the Pacific coast of Mexico (Gárate-Lizárraga et al. 2007, 2010; Maciel-Baltazar \& Hernández-Becerril 2013). Including $C$. falcatum, a total of 21 species belonging to 5 orders of naked dinoflagellates were identified during this bloom (Table 1; Figs. 2-3). The most representative order was Gymnodiniales with 14 species (Table 1). Gymnodinium gelbum, Gyrodinium lachryma, and Takayama tasmanica are new records for the Pacific coast of Mexico. Achradina pulchra, Gyrodinium acutum, Karenia bicuneiformis and Pronoctiluca spinifera are new records for the Gulf of California. The measurements and regional distribution data for each species are given and the species are alphabetically arranged. 

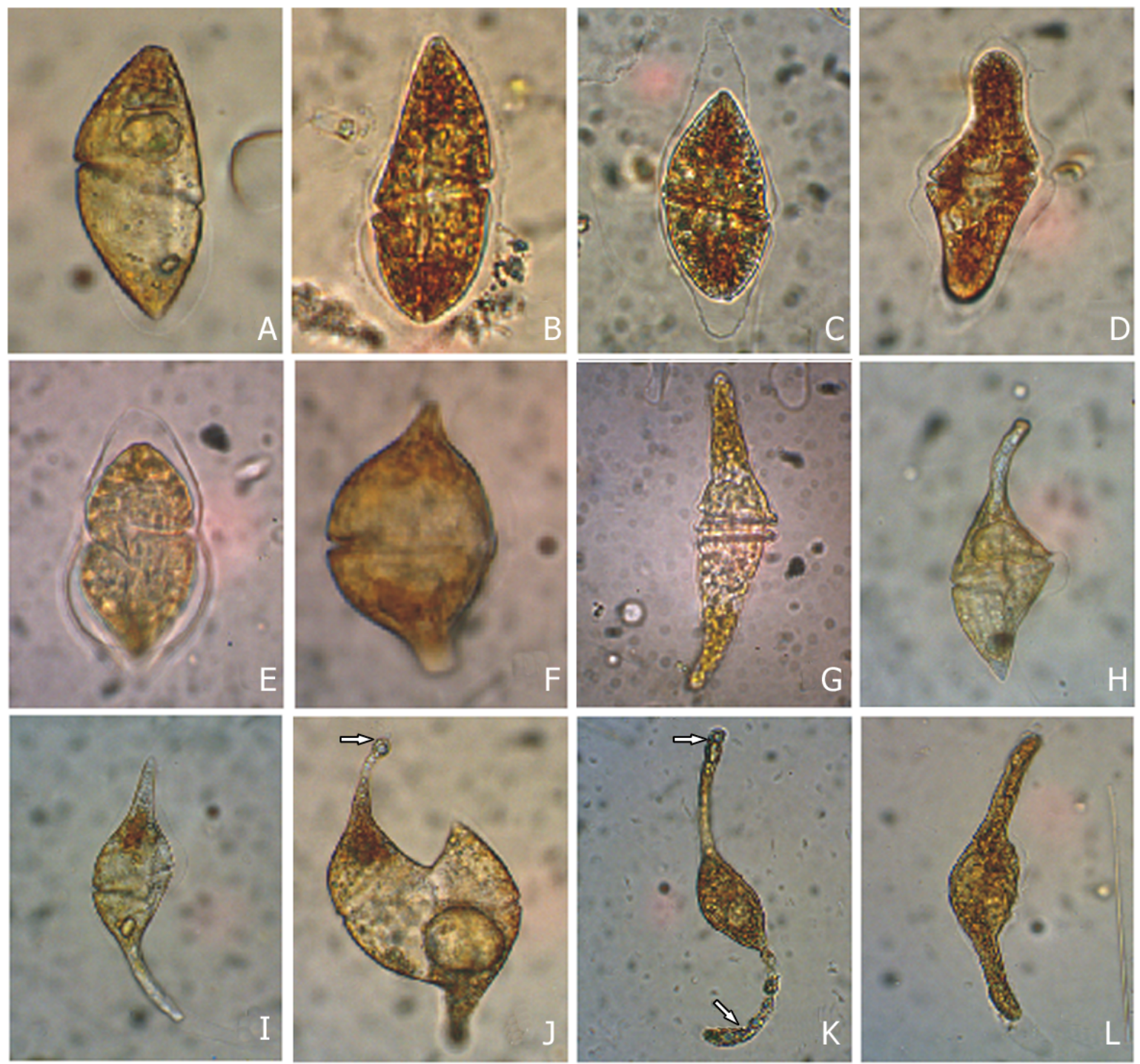

Figure 2. Micrographs of different stages in the life cycle stages of Ceratoperidinium falcatum in Bahía de La Paz. A-F) Immature specimens at the stage of hyaline cysts; G-L) M ature specimens; J) A dividing mature specimen of C. falcatum; K-L) Two specimens of $C$. falcatum fixed in Lugol's solution. Arrows indicate well-diferentiated articulate cells with generative functions of the mother sporont / Microfotografías de diferentes estadios del ciclo de vida de Ceratoperidinium falcatum encontrados en Bahía de La Paz. A-F) Especímenes inmaduros en estado de quistes hialinos; G-L) Especímenes maduros; J) Un espécimen maduro de C. falcatum dividiéndose; K-L) Dos especímenes maduros de C. falcatum fijados con Lugol. Las flechas indican células articuladas bien diferenciadas que tienen funciones generativas del esporonte madre 

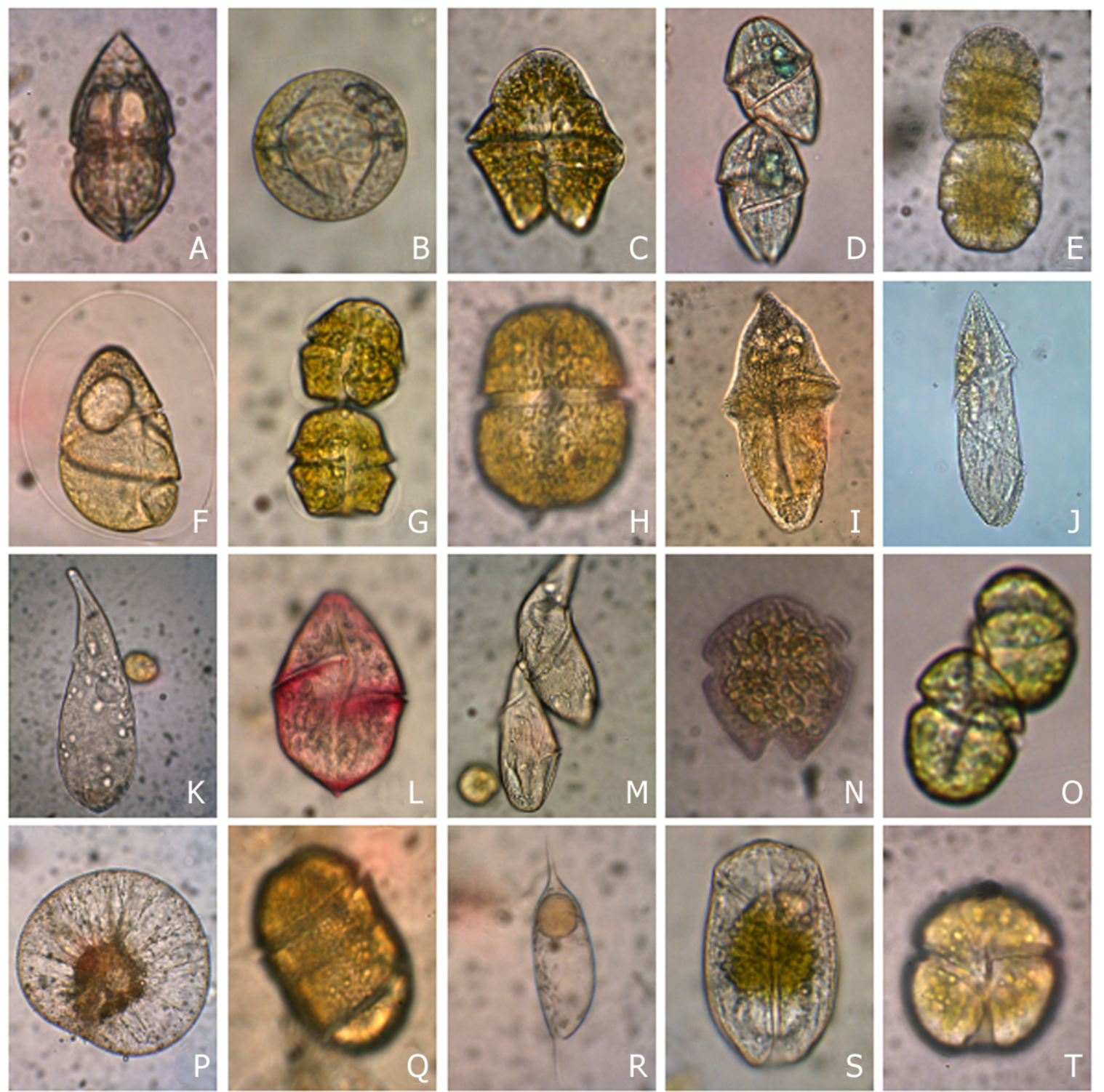

Figure 3. Light microphotographs of unarmored dinoflagellates detected during the proliferation of Ceratoperidinium falcatum in Bahía de La Paz. A) Achradina pulchra, B) Actiniscus pentasterias, C) Akashiwo sanguinea, D) Two-celled chain of Balechina coerulea, E) Cochlodinium fulvescens, F) Hyaline cyst of Cochlodinium pirum, G) Gymnodinium catenatum, H) Gymnodinium gelbum, I) Gymnodinium gracile, J) Gyrodinium acutum, K) Gyrodinium lachryma, L) Gyrodinium rubrum, M) Gyrodinium spirale, N) Karenia bicuneiformis, 0) Two cells of Lepidodinium chlorophorum, P) Noctiluca scintillans, Q) Two-celled chain of Polykrikos hartmannii, R) Pronoctiluca spinifera, S) Immature specimen of Spatulodinium pseudonoctiluca, T) Takayama tasmanica / Microfotografías de luz de dinoflagelados desnudos detectados durante la proliferación de Ceratoperidinium falcatum en la Bahía de La Paz. A) Achradina pulchra, B) Actiniscus pentasterias, C) Akashiwo sanguinea, D) Cadena de dos células de Balechina coerulea, E) Cochlodinium fulvescens, F) Quiste hialino de Cochlodinium pirum, G) Gymnodinium catenatum, H) Gymnodinium gelbum, I) Gymnodinium gracile, J) Gyrodinium acutum, K) Gyrodinium lachryma, L) Gyrodinium rubrum, M) Gyrodinium spirale, N) Karenia bicuneiformis, O) Dos células de Lepidodinium chlorophorum, P) Noctiluca scintillans, Q) Cadena de dos células de Polykrikos hartmannii, R) Pronoctiluca spinifera, S) Espécimen inmaduro de Spatulodinium pseudonoctiluca, T) Takayama tasmanica 
Table 1. Abundance of unarmored dinoflagellates detected during the proliferation of Ceratoperidinium falcatum at 16-17 January 2013 in Bahía de La Paz / Abundancia de dinoflagelados desnudos detectados durante la proliferación de Ceratoperidinium falcatum entre el 16-17 de enero 2013, en Bahía de La Paz

\begin{tabular}{|c|c|c|c|c|c|}
\hline Unarmored dinoflagellates species & Order & $\begin{array}{c}\text { Station } 1 \\
\left(\text { cells } L^{-1} \text { ) }\right. \\
16 / 01 / 2013\end{array}$ & $\begin{array}{c}\text { Station } 1 \\
\text { (cells L }{ }^{-1} \text { ) } \\
17 / 01 / 2013\end{array}$ & $\begin{array}{c}\text { Station } 2 \\
\left(\text { cells L }{ }^{-1}\right) \\
16 / 01 / 2013\end{array}$ & $\begin{array}{c}\text { Station } 2 \\
\left(\text { cells L }{ }^{-1}\right) \\
17 / 01 / 2013\end{array}$ \\
\hline Achradina pulchra & Amphilothales & 200 & 0 & 0 & 200 \\
\hline Actiniscus pentasterias & Actiniscales & 200 & 0 & 600 & 1200 \\
\hline Akashiwo sanguinea & Gymnodiniales & 0 & 0 & 600 & 200 \\
\hline Ceratoperidinium falcatum & Gymnodiniales & 24400 & 11200 & 145400 & 52800 \\
\hline Balechina coerulea & Gymnodiniales & 400 & 400 & 200 & 200 \\
\hline Cochlodinium fulvescens & Gymnodiniales & 7600 & 10800 & 4400 & 600 \\
\hline Cochlodinium pirum & Gymnodiniales & 0 & 0 & 400 & 0 \\
\hline Gymnodinium catenatum & Gymnodiniales & 28200 & 5800 & 7200 & 11400 \\
\hline Gymnodinium gelbum & Gymnodiniales & 1200 & 200 & 400 & 600 \\
\hline Gymnodinium gracile & Gymnodiniales & 0 & 0 & 600 & 400 \\
\hline Gyrodinium acutum & Gymnodiniales & 200 & 0 & 200 & 0 \\
\hline Gyrodinium lachryma & Gymnodiniales & 0 & 0 & 400 & 200 \\
\hline Gyrodinium rubrum & Gymnodiniales & 800 & 0 & 400 & 0 \\
\hline Gyrodinium spirale & Gymnodiniales & 1200 & 200 & 200 & 0 \\
\hline Karenia bicuneiformis & Brachidiniales & 400 & 0 & 800 & 0 \\
\hline Lepidodinium chlorophorum & Gymnodiniales & 200 & 0 & 0 & 400 \\
\hline Noctiluca scintillans & Noctilucales & 4200 & 200 & 28800 & 2400 \\
\hline Polykrikos hartmannii & Gymnodiniales & 0 & 0 & 800 & 0 \\
\hline Spatulodinium pseudonoctiluca & Noctilucales & 200 & 0 & 800 & 0 \\
\hline Pronoctiluca spinifera & Noctilucales & 200 & 200 & 200 & 0 \\
\hline Takayama tasmanica & Brachidiniales & 400 & 0 & 600 & 0 \\
\hline $\begin{array}{l}\text { Total unarmored dinoflagellates } \\
\text { abundance }\end{array}$ & & 70000 & 29000 & 193000 & 70600 \\
\hline
\end{tabular}

\section{ACHRADINA PULCHRa LoHMAnN (Fig. 3A)}

References: Schiller 1937, p. 5, figs. 2 a-c; HernándezBecerril \& Bravo-Sierra 2004, p. 420, figs. 5-8; Meave del Castillo et al. 2012, 426, figs. 43-44; Omura et al. 2012, p. 134, Achradina pulchra (a-f).

Dimensions: cells are 34-42 $\mu \mathrm{m}$ long and 18-26 $\mu \mathrm{m}$ wide.

Regional distribution: Recorded from the west coast of Baja California Peninsula, to the Gulf of Tehuantepec (Hernández-Becerril \& Bravo-Sierra 2004). Recently reported in Bahía de Acapulco (Meave del Castillo et al. 2012). This is the first record for the Gulf of California.
Actiniscus PENTASTERIaS (EHRENBERG) Ehrenberg (FIG. 3B)

Basionym: Dictyota pentasterias Ehrenberg

References: Hernández-Becerril \& Bravo-Sierra 2004, p. 419, figs. 2-4; Hoppenrath et al. 2009, p. 132, fig. 55g-h; Gárate-Lizárraga 2012, p. 46, figs. 73-74; Omura et al. 2012, p. $\mathrm{O} 75$, Actiniscus pentasterias (a-f).

Dimensions: cells are 32-50 $\mu \mathrm{m}$ long and 32-40 $\mu \mathrm{m}$ wide.

Regional distribution: recorded along the west coast of the Baja California Peninsula and from the Gulf of California to the Gulf of Tehuantepec (Okolodkov \& GárateLizárraga, 2006, Gárate-Lizárraga 2012, Gárate-Lizárraga et al. 2014). 
Akashiwo sanguinea (K.Hirasaka) G.Hansen \& Ø.Moestrup (Fig. 3C)

Basionym: Gymnodinium sanguineum K.Hirasaka

Synonyms: G. splendens M. Lebour, G. nelsonii G.W. Martin

References: Lebour 1925: 43, pl. 5, fig. 1; Avancini et al. 2006, p. 265, figs. A-C; Hoppenrath et al. 2009, p. 124, figs. 53k-1; Hallegraeff et al. 2010, p. 147, fig. 1.

Dimensions: cells are 40-86 $\mu \mathrm{m}$ long and 30-52 $\mu \mathrm{m}$ wide.

Regional distribution: bloom-forming species found along the Pacific coast of Mexico (Gárate-Lizárraga et al. 2001, 2007, 2014; Okolodkov \& Gárate-Lizárraga 2006).

Balechina coerulea (Dogiel) F.J.R.TAYlor (Fig. 3D)

Basionym: Gymnodinium coeruleum Dogiel

References: Taylor 1976, p. 113, pl. 37, fig. 447; pl. 40, fig. 481; Steidinger \& Tangen 1997, p. 461; Gárate-Lizárraga et al. 2009 p. 22, fig. 20.

Dimensions: cells are 98-102 $\mu \mathrm{m}$ long and 50-53 $\mu \mathrm{m}$ wide.

Regional distribution: along the Pacific coast of Mexico (Okolodkov \& Gárate-Lizárraga 2006, Meave del Castillo et al. 2012, Maciel-Baltazar \& Hernández-Becerril 2013).

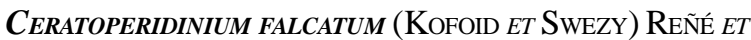
de Salas (FIgs. 2A-L)

Basionym: Gyrodinium falcatum Kofoid \& Swezy 1921

Synonyms: Gymnodinium fusus Schütt (1895) per parte, incl. only fig. 81 , pl. 25. G. caudatum, Pseliodinium vaubanii Sournia (1972).

References: Okolodkov \& Dodge 1997: 356, figs. 3-8, $27-$ 28; Konovalova 2003, p. 169, figs. 1-9; Gómez 2007, p. 275, figs. 2-22; Gárate-Lizárraga et al. 2010, p. 54, figs. 221; Reñé et al. 2013, p. 678, figs. 3a-c.

Dimensions: mature individuals are 40-190 $\mu \mathrm{m}$ long and 20-36 $\mu \mathrm{m}$ wide.

Regional distribution: well-distributed along the Pacific coast of Mexico (Okolodkov \& Gárate-Lizárraga 2006, Gárate-Lizárraga et al. 2010, Maciel-Baltazar \& HernándezBecerril 2013).

Cochlodinium fulvescens M. IWATAKI, H. KaWAMI \& K. Matsuoka (Fig. 3E)

References: Iwataki et al. 2007, p. 235, figs. 1-9; Matsuoka et al. 2008 p. 264, figs. 3A-G. Morquecho-Escamilla \& Alonso-Rodríguez 2008, p. 5, figs. 2A-C.
Dimensions: cells are 50-64 $\mu \mathrm{m}$ long and 38-42 $\mu \mathrm{m}$ wide.

Regional distribution: has been reported in Bahía de La Paz (Gárate-Lizárraga et al. 2009, Gárate-Lizárraga 2014), Bahía de Mazatlán (Morquecho-Escamilla \& AlonsoRodríguez 2008) and Bahía de Acapulco (Meave del Castillo et al. 2012).

\section{Cochlodinium PIRUM (SchÜTT) LEMMERMANN (FIG. 3F)}

Basionym: Gymnodinium pirum Schütt

References: Schütt 1895 p. 166, pl. 23, figs. 76: 1-4; Kofoid \& Swezy 1921, p. 374, pl. 9, fig. 101; text figure GG, 3.

Dimensions: cells are $68-70 \mu \mathrm{m}$ long and $38-42 \mu \mathrm{m}$ wide.

Regional distribution: recorded once for the Pacific coast of Mexico (Caballasi-Flores 1985). This is the first report in the Bahía de La Paz.

\section{Gymodinium Catenatum H.W. GRAhAM (FIG. 3G)}

References: Graham 1943, p. 259, figs. 1-2; CortésAltamirano et al. 1999, p. 52, figs. 2a-c; Gárate-Lizárraga et al. 2004b, p. 298, figs. 2A-D.

Dimensions: cells are 28-40 $\mu \mathrm{m}$ long and 30-32 $\mu \mathrm{m}$ wide.

Regional distribution: broadly distributed along the Mexican Pacific (Okolodkov \& Gárate-Lizárraga 2006, Band-Schmidt et al. 2010). It is the main species responsible for red tides along the Pacific coast of Mexico (Graham 1943, Mee et al. 1986, Cortés-Altamirano et al. 1999, Gárate-Lizárraga et al. 2004b, 2009, Díaz-Ortíz et al. 2010, Quijano-Scheggia et al. 2012).

\section{Gymadinium gelbum Kofoid (Fig. 3H)}

References: Kofoid 1931, p. 13, pl 1. fig. 1; Wood 1968, p. 65, fig 163; Elbrächter 1979, p. 7, figs. 10-11,

Dimensions: cells are 42-51 $\mu \mathrm{m}$ long and 34-36 $\mu \mathrm{m}$ wide.

Regional distribution: first record for the Pacific coast of Mexico. Few records of G. gelbum have been reported worldwide (Kofoid 1931, Wood 1963, 1968, Elbrächter 1979). In the past, it is possible that specimens fixed in Lugol's solution could be confused with single cells of Gymnodinium catenatum because they are very similar.

\section{Gymadinium gracile BeRgh (Fig. 3I)}

References: Elbrächter 1979, p. 7, figs. 12-15, Hoppenrath et al. 2009, p. 124, figs. 53a-f; Gárate-Lizárraga 2012, p. 46, fig. 67. 
Dimensions: cells are 85-129 $\mu \mathrm{m}$ long and 50-65 $\mu \mathrm{m}$ wide.

Regional distribution: broadly distributed along the Pacific coast of Mexico (Okolodkov \& Gárate-Lizárraga 2006, Gárate-Lizárraga 2012).

Gyrodinium acutum (SchütT) KofoId \& SweZy (Fig. 3J) Basionym: Gyrodinium spirale var. acuta Schütt

References: Schütt 1895, p. 164, pl. 21, fig. 66 Kofoid \& Swezy 1921, p. 274, fig. CC, 7.

Dimensions: cells are 136-140 $\mu \mathrm{m}$ long and 40-43 $\mu \mathrm{m}$ wide.

Regional distribution: previously reported in the Bahía de Acapulco, Guerrero (Meave del Castillo et al. 2012). This is the first report in the Gulf of California.

\section{Gyrodinium lachryma (Meunier) Kofoid \& Swezy (Fig.} $3 \mathrm{~K})$

Basionym: Spirodinium lachryma Meunier

References: Kofoid \& Swezy 1921, p. 314, fig. EE, 6; Lebour 1925, p. 43, fig. 14c; Dodge 1982, p. 98, fig. 12C; Hallegraeff et al. 2010, p. 155, fig. 4.6A

Dimensions: cells are 90-112 $\mu \mathrm{m}$ long and 40-52 $\mu \mathrm{m}$ wide.

Regional distribution: new record for the Pacific coast of Mexico.

Gyrodinium rubrum (Kofoid \& Swezy) TAKano \& T.Horiguichi (FIG. 3L)

Basionym: Gymnodinium rubrum Koifoid \& Swezy

References: Kofoid \& Swezy 1921, p. 253, fig. A, Y4, pl. 8, fig. 86 .

Dimensions: cells are 70-120 $\mu \mathrm{m}$ long and 30-59 $\mu \mathrm{m}$ wide.

Regional distribution: this species have been previously reported twice; Meave del Castillo \& Hernández-Becerril (1998) in the Gulf of Tehuantepec, Oaxaca and in Bahía de La Paz (Okolodkov \& Gárate-Lizárraga 2006). This is the second report for Bahía de La Paz.

Gyrodinium SPIRAle (BerGH) Kofoid \& SweZy (Fig. 3M)

Basionym: Gymnodinium spirale Bergh

References: Kofoid \& Swezy 1921, p. 332, pl. 4, fig. 43, fig. DD, 14; Hulburt 1957, p. 202, pl. 3, fig. 4, Hallegraeff et al. 2010, p. 155 , fig. $4.6 \mathrm{~B}$.
Dimensions: cells are 70-96 $\mu \mathrm{m}$ long and 34-38 $\mu \mathrm{m}$ wide.

Regional distribution: broadly distributed along the Pacific coast of Mexico (Okolodkov \& Gárate-Lizárraga 2006). Densities of 30,000 cells L ${ }^{-1}$ were reported in Bahía de La Paz (Gárate-Lizárraga et al. 2009). Blooms of this species have occurred in shrimp farms with densities ranging from 424 to $1200 \times 10^{3}$ cells $\mathrm{L}^{-1}$.

Karenia bicuneiformis Botes, Sym \& Pitcher (Fig. 3N) References: Botes et al. 2003, p. 566-568, figs. 10-19; Hallegraeff et al. 2010, p. 149, fig. 4.4A-D; Maciel-Baltazar \& Hernández-Becerril 2013, p. 248, fig. 20.

Dimensions: cells are 32-36 $\mu \mathrm{m}$ long and 30-34 $\mu \mathrm{m}$ wide.

Regional distribution: Meave del Castillo \& ZamudioReséndiz (2012) report that $K$. bicuneiformis is restricted to Bahía de Acapulco and the Gulf of Tehuantepec; also reported by Maciel-Baltazar \& Hernández-Becerril (2013). This is the first record for the Gulf of California.

LEPIDOdINIUM CHLOROPHORUM (M. ELBRÄCHTER \& E. Schnepf) Gert Hansen, L. Botes \& M. de Salas (Fig. 3O)

Basionym: Gymnodinium chlorophorum M. Elbrächter \& E. Schnepf

References: Elbrächter \& Schnepf 1996, p. 382, gs. 1-3; Hoppenrath et al. 2009, p. 124, fig. 53g; Hallegraeff et al. 2010, p. 147, fig. 4.2G, Omura et al. 2012, p. 76, Lepidodinium chlorophorum (a-h).

Dimensions: cells are 20-26 $\mu \mathrm{m}$ long and 14-16 $\mu \mathrm{m}$ wide.

Regional distribution: This species was previously recorded by Gárate-Lizárraga et al. (2014) in Bahía de La Paz. This is the second record for the Pacific coast of Mexico. Two-celled specimens of $L$. chlorophorum were observed. The formation of chains is not known in this species. Therefore they could be fusing or dividing cells.

Noctiluca SCINTIllans (MaCARTNEy) KofOID \& SweZY (FIG. 3P)

Basionym: Medusa scintillans Macartney

Referencias: Steidinger \& Tangen 1997, p. 466, pl. 23; Avancini et al. 2006, p. 361, figs. A-C; Esqueda-Lara \& Hernández-Becerril 2010, p. 179, figs. 172a-b.

Dimensions: cells are $410-800 \mu \mathrm{m}$ in diameter. 
Regional distribution: Broadly distributed along the Pacific coast of Mexico (Okolodkov \& Gárate-Lizárraga 2006). One of the most common species that form red tides in the Gulf of California (Gárate-Lizárraga et al. 2001, 2006).

\section{Polykrikos haRtmanNi ZimmermanN (Fig. 3Q)}

Taxonomic synonym: Pheopolykrikos hartmannii (Zimmerman) Matsuoka \& Fukuyo References: Hulburt 1957, p. 204, pl. 4, fig. 7, Gárate-Lizárraga et al. 2009, p. 21, figs. 30, 31; Hoppenrath et al. 2009, p. 31, figs. 2A-C.

Dimensions: cells are 70-74 $\mu \mathrm{m}$ long and 60-64 $\mu \mathrm{m}$ wide.

Regional distribution: Scarcely reported in the Pacific coast of Mexico (Okolodkov \& Gárate-Lizárraga 2006, Gárate-Lizárraga et al. 2009). It was recently recorded in the Gulf of Tehuantepec (Maciel-Baltazar \& HernándezBecerril 2013).

Pronoctiluca SPINifera (Lohmann) Schiller (Fig. 3R) References: Taylor 1976, p. 188, pl. 37, fig. 429; Dodge 1982, p. 112, fig. 13G; Omura et al. 2012, p. 133, Pronoctiluca spinifera (a-d), Maciel-Baltazar \& Hernández-Becerril 2013, p. 188, fig. 3G.

Dimensions: cells are $22-26 \mu \mathrm{m}$ long and 10-14 $\mu \mathrm{m}$ wide.

Regional distribution: scarcely reported along the west coast of Baja California Sur (Gárate-Lizárraga et al. 2007); recently in the Gulf of Tehuantepec (Maciel-Baltazar \& Hernández-Becerril 2013). This is the first report for the Gulf of California.

\section{Spatulodinium pseudonoctiluca (Pouchet) CAChon \&} Cachon ex Loeblich \& Loeblich (Fig. 3S)

Basionym: Gymnodinium pseudonoctiluca Pouchet

References: Dodge 1982, p. 136, fig. 16D; Avancini et al. 2006, p. 413, figs. A-C; Hoppenrath et al. 2009, p. 132, figs. 55g-h; Gárate-Lizárraga 2011, p. 35, figs. 11-14.

Dimensions: young cells are 82-86 $\mu \mathrm{m}$ long and 34-42 $\mu \mathrm{m}$ wide.

Regional distribution: from Bahía Magdalena to the Gulf of Tehuantepec (Okolodkov \& Gárate-Lizárraga 2006, Gárate-Lizárraga 2011).
Takayama tasmanica de Salas, Bolch \& Hallegraeff (FIG. 3T)

References: de Salas et al. 2003, p. 1235, fig. 2-12; Hallegraeff et al. 2010, 149, figs. 4.4E-G.; Gu et al. 2013, 260, figs. 21-27.

Dimensions: cells are 16-27 $\mu \mathrm{m}$ long and 14-26 $\mu \mathrm{m}$ wide.

Regional distribution: this is the first record for the Pacific coast of Mexico.

In Bahía de La Paz, monitoring of live microalgae that form red tides started in 2000 during a bloom of $C$. polykrikoides (Gárate-Lizárraga et al. 2004a). Since then, many microalgae bearing a soft cell membrane (dinoflagellates and raphidophytes) have been identified (Gárate-Lizárraga et al. 2004a; 2009). Correct identification of naked dinoflagellates in Bahía de $\mathrm{La} \mathrm{Paz}$ is a good example of the importance of working with fresh samples. The morphology of naked dinoflagellates changes during observation under a light microscope. Likewise, cells tend to form an outer hyaline membrane or a temporary hyaline cyst (Figs. 2A-E and Fig. 3F); otherwise, they would explode. Specimens fixed with Lugol's solution could not always be correctly identified. Live samples are important when studying unarmored species and other naked dinoflagellates. Nevertheless, molecular analyses could be performed to combine the morphological and molecular information.

\section{ACKNOWLEDGMENTS}

The projects were funded by grants from the Instituto Politécnico Nacional (SIP-20130549, SIP-20141181 and SIP20141095). I.G.L is a COFAA and EDI fellow. Thanks to María Clara Ramírez-Jáuregui (ICMyL-UNAM, Mazatlán) for the literature search. I also thank the anonymous reviewers who provided useful comments and suggestions which help to improve the manuscript.

\section{LITERATURE CITED}

Alonso-Rodríguez R, ED Frausto-Sotelo \& SA BarónCampis. 2010. Registro de Gyrodinium falcatum (Kofoid and Swezy, 1921) en dos regiones del Pacífico Mexicano. En: Vargas-Amado G, O Vargas-Ponce, A RodríguezContreras, M Harker \& AS Monroy-Sais. XVIII Congreso Mexicano de Botánica, 81-82 pp. Guadalajara, Jalisco, México. Prometeo Editores S.A. de C.V. 
Avancini M, AM Cicero, I Di Girolamo, M Innamorati, E Magaletti, T Sertorio \& T Zunini. 2006. Guida al riconoscimento del plancton dei mari italiani, Vol. I. Fitoplancton, 503 pp. Ministero dell'Ambiente e della Tutela del Territorio e del Mare, ICRAM, Rome.

Band-Schmidt CJ, J Bustillos-Guzmán, D López-Cortés, I Gárate-Lizárraga, EJ Núñez-Vázquez \& FE Hernández-Sandoval. 2010. Ecological and physiological studies of Gymnodinium catenatum in the Mexican Pacific: A Review. Marine Drugs 8: 1935-1961.

Botes L, SD Sym \& GC Pitcher. 2003. Karenia cristata sp. nov. and Karenia bicuneiformis sp. nov. (Gymnodiniales Dinophyceae): two new Karenia species from the South Africa coast. Phycologia 42: 563-571.

Caballasi-Flores P. 1985. Comparación fitoplanctónica de la Bahía de Mazatlán y el Estero de Urías, Sin., México, 1981. Tesis de Licenciatura, Escuela Nacional de Estudios Profesionales Zaragoza, Universidad Nacional Autónoma de México, Ciudad de México, 50 pp.

Cortés-Altamirano R. 2002. Mareas rojas: biodiversidad de microbios que pintan el mar. En: Cifuentes JL \& J GaxiolaLópez (eds). Atlas de biodiversidad de Sinaloa, pp. 29-41. Colegio de Sinaloa, Guadalajara.

Cortés Altamirano R, A Nuñez-Pasten \& N Pastén-Miranda. 1999. Abundancia anual de Gymnodinium catenatum Graham dinoflagelado tóxico de la costa este del Golfo de California. Ciencia y Mar 3: 50-56.

De Salas MF, CJS Bolch, L Botes, G Nash, SW Wright \& GM Hallegraeff. 2003. Takayama gen. nov. (Gymnodiniales, Dinophyceae), a new genus of unarmored dinoflagellates with sigmoid apical grooves, including the description of two new species Journal of Phycology 39: 1233-1246.

Díaz-Ortíz JA, B Pérez-Cruz, R Valdovinos-Sánchez, MA Alarcón-Romero, $S$ López-Silva, L Chávez-Almazán \& JL García-Barboza. 2010. Registro histórico de marea roja en la Bahía de Acapulco de 1992 a 2010 Red Sanitaria 7: $1-4$.

Dodge JD. 1982. Marine dinoflagellates of the British Isles, 303 pp. Her Majesty's Stationery Office, London.

Elbrächter M. 1979. On the taxonomy of unarmoured dinophytes (Dinophyta) from the Northwest African upwelling region. Meteor Forschungergebnisse Reihe 30: $1-22$.

Elbrächter M \& E Schnepf. 1996. Gymnodinium chlorophorum, a new green, bloom-forming dinoflagellate (Dinophyceae, Gymnodiniales) with a vestigial prasinophyte endosymbiont. Phycologia 35: 381-393.

Esqueda-Lara K \& DU Hernández-Becerril. 2010. Dinoflagelados microplanctónicos marinos del Pacífico central de México (Isla Isabel, Nayarit y costas de Jalisco y Colima), 206 pp. Instituto de Ciencias del Mar y Limnología, Universidad Nacional Autónoma de México, Ciudad de México.
Gárate-Lizárraga I. 2011. New data on the distribution of Spatulodinium pseudonoctiluca (Noctilucales: Kofoidiniaceae) in the Mexican Pacific. CICIMAR Oceánides 26: 33-41.

Gárate-Lizárraga I. 2012. Proliferation of Amphidinium carterae (Gymnodiniales: Gymnodiniaceae) in Bahía de La Paz, Gulf of California. CICIMAR Oceánides 27: 1-13.

Gárate-Lizárraga I. 2014. Occurrence of Cochlodinium fulvescens (Gymnodiniales: Dinophyceae) in the southwestern Gulf of California. Revista de Biología Marina y Oceanografía 49: 123-127.

Gárate-Lizárraga I, ML Hernández-Orozco, CJ BandSchmidt \& G Serrano-Casillas. 2001. Red tides along the coasts of Baja California Sur, Mexico (1984-2001). Oceánides 16: 127-134.

Gárate-Lizárraga I, DJ López-Cortés, JJ BustillosGuzmán \& FE Hernández-Sandoval. 2004a. Blooms of Cochlodinium polykrikoides (Gymnodiniaceae) in the Gulf of California, Mexico. Revista de Biología Tropical 52 (Supl.1): 51-58.

Gárate-Lizárraga I, JJ Bustillos-Guzmán, R AlonsoRodríguez \& B Luckas. 2004b. Comparative paralytic shellfish toxin profiles in two marine bivalves during outbreaks of Gymnodinium catenatum (Dinophyceae) in the Gulf of California. Marine Pollution Bulletin 48: 378-402.

Gárate-Lizárraga I, MS Muñetón-Gómez \& V MaldonadoLópez. 2006. Florecimiento del dinoflagelado Gonyaulax polygramma frente a la Isla Espíritu Santo, Golfo de California (Octubre 2004). Revista de Investigaciones Marinas 27(1): 31-39.

Gárate-Lizárraga I, CJ Band-Schmidt, G Verdugo-Díaz, MS Muñetón-Gómez \& EF Félix-Pico. 2007. Dinoflagelados (Dinophyceae) del Sistema Lagunar Magdalena-Almejas. In: Funes-Rodríguez R, J GómezGutiérrez \& R Palomares-García (eds). Estudios ecológicos en Bahía Magdalena, pp. 145-175. Comité Editorial del IPN, La Paz, Baja California Sur.

Gárate-Lizárraga I, CJ Band-Schmidt, F Aguirre-Bahena \& T Grayeb-del Álamo. 2009. A multi-species microalgae bloom in Bahía de La Paz, Gulf of California, Mexico (June 2008). CICIMAR Oceánides 24(1): 1-15.

Gárate-Lizárraga I, E Muciño-Márquez \& DJ LópezCortés. 2010. Estadios de vida de Gyrodinium falcatum (Dinophyceae) en la Bahía de La Paz, Golfo de California. CICIMAR Oceánides 25: 53-58.

Gárate-Lizárraga I, MS Muñetón-Gómez, B Pérez-Cruz \& JA Díaz-Ortíz. 2014. Bloom of Gonyaulax spinifera (Dinophyceae: Gonyaulacales) in Ensenada de La Paz lagoon, Gulf of California. CICIMAR Oceánides 29(1): 11-18.

Gómez F. 2007. Gymnodinioid dinoflagellates (Gymnodiniales, Dinophyceae) in the open Pacific Ocean. Algae 22: 273-286. 
Gómez-Valdés J, JA Delgado \& JA Dwora. 2003. Overtides, compound tides, and tidal-residual current in Ensenada de la Paz lagoon, Baja California Sur, Mexico. Geofísica Internacional 42: 623-634.

Graham HW. 1943. Gymnodinium catenatum, a new dinoflagellate from the Gulf of California. Transactions of the American Microscopical Society 62: 259-261.

Gu H, Z Luo, X Zhang, B Xu \& Q Fang. 2013. Morphology, ultrastructure and phylogeny of Takayama xiamenensis sp. nov. (Gymnodiniales, Dinophyceae) from the East China Sea. Phycologia 52: 256-265.

Hallegraeff GM, CJS Bolch, JMS Huisman \& MF de Salas. 2010. Planktonic dinoflagellates. In: Hallegraeff GM, CJS Bolch, DRA Hill, I Jameson, JM LeRoi, A McMinn, S Murray, MF de Salas \& K Saunders (eds). Algae of Australia: Phytoplankton of temperate coastal waters, pp. 145-212. CSIRO Publishing, Collingwood.

Hernández-Becerril DU \& E Bravo-Sierra. 2004. New records of planktonic dinoflagellates (Dinophyceae) from the Mexican Pacific Ocean. Botanica Marina 47: 417-423.

Hoppenrath M, M Elbrächter \& G Drebes. 2009. Marine phytoplankton: Selected microphytoplankton species from the North Sea around Helgoland and Sylt, 264 pp. Schweitzerbarth Verlag, Stuttgart.

Hulburt EM. 1957. The taxonomy of unarmored Dinophyceae of shallow embayments on Cape Cod, Massachusetts. The Biological Bulletin 112: 196-219.

Iwataki M, H Kawami \& K Matsuoka. 2007. Cochlodinium fulvescens sp. nov. (Gymnodiniales, Dinophyceae), a new chain forming unarmored dinoflagellate from Asian coasts. Phycological Research 55: 231-239.

Kofoid CA. 1931. Report of the biological survey of Mutsu Bay. 18. Protozoan fauna of Mutsu Bay. Subclass Dinoflagellata; Tribe Gymnodinoidae. Science Reports of Tohoku Imperial University, Fourth Series 6(1): 1-43.

Kofoid CA \& O Swezy. 1921. The free-living unarmored dinoflagellata. Memoirs of the University of California, 562 pp. University of California Press, Berkeley.

Konovalova GV. 2003. The life history of Gyrodinium falcatum and validity of Pseliodinium vaubanii (Dinophyceae). Russian Journal of Marine Biology 29: 167-170.

Lebour MV. 1925. The dinoflagellates of the Northern Seas, 250 pp. Marine Biological Association of the United Kingdom, Plymouth.

Maciel-Baltazar E \& DU Hernandez-Becerril. 2013. Especies de dinoflagelados atecados (Dinophyta) de la costa de Chiapas, sur del Pacífico mexicano. Revista de Biología Marina y Oceanografía 48: 245-259.

Matsuoka K, M Iwataki \& H Kawami. 2008. Morphology and taxonomy of chain-forming species of the genus Cochlodinium (Dinophyceae). Harmful Algae 7: 261-270.
Meave del Castillo ME \& DU Hernández-Becerril. 1998. Fitoplancton. En: Tapia-García M (ed). El Golfo de Tehuantepec: el ecosistema y sus recursos, pp. 59-74. Universidad Autónoma Metropolitana, Iztapalapa.

Meave del Castillo ME \& ME Zamudio-Reséndiz. 2012. Karenia species in the Mexican Pacific. In: Pagou K \& G Hallegraeff (eds). Proceedings of the 14th International Conference on Harmful Algae, Heersonissos-Creta, Greece, 1-5 November, 2010, pp. 122-124. International Society for the Study of Harmful Algae / Intergovernmental Oceanographic Commission of UNESCO.

Meave del Castillo ME, ME Zamudio-Resendiz \& M Castillo-Rivera. 2012. Riqueza fitoplanctónica de la Bahía de Acapulco y zona costera aledaña, Guerrero, México. Acta Botanica Mexicana 100: 405-487.

Mee LD, M Espinosa \& G Díaz. 1986. Paralytic shellfish poisoning with a Gymnodinium catenatum red tide on the Pacific coast of Mexico. Marine Environmental Resources 19: 17-92.

Morquecho-Escamilla ML \& R Alonso-Rodríguez. 2008. First record of Cochlodinium fulvescens in Mexican Pacific. Harmful Algae News 37: 5-6.

Reñé A, M de Salas, J Camp, V Balagué \& E Garcés. 2013. A new clade, based on partial LSU rDNA sequences, of unarmoured dinoflagellates. Protist 164: 673-685.

Okolodkov YB \& JD Dodge. 1997. Morphology of some rare and unusual dinoflagellates from the north-eastern Atlantic. Nova Hedwigia 54(3-4): 353-365.

Okolodkov YB \& I Gárate-Lizárraga. 2006. An annotated checklist of dinoflagellates (Dinophyceae) from the Mexican Pacific. Acta Botanica Mexicana 74: 1-154.

Omura T, M Iwataki, VM Borja, H Takayama \& Y Fukuyo. 2012. Marine phytoplankton of the Western Pacific, 160 pp. Kouseisha Kouseikaku, Tokyo.

Quijano-Scheggia S, A Olivos-Ortiz, JJ BustillosGuzmán, E Garcés, JH Gaviño-Rodríguez, MA GaliciaPérez, M Patiño-Barragán, CJ Band-Schmidt, FE Hernández-Sandoval \& DJ López-Cortés. 2012. Bloom of Gymnodinium catenatum in Bahía Santiago and Bahía Manzanillo, Colima, México. Revista de Biología Tropical 60: 173-186.

Schiller J. 1937. Dinoflagellate (Peridineae). In: Rabenhorst L (ed). Kryptogamen-Flora of Deutschland, Österreich und der Schweiz, Vol. 2: 1-590. Akademische Verlagsgesellschaft, Leipzig.

Schütt F. 1895. Die Peridineen der Plankton-Expedition. Ergebnisse der Plankton-Expedition der Humboldt-Stiftung 4: 1-170.

Steidinger KA \& K Tangen. 1997. Dinoflagellates. In: Tomas CR (ed). Identifying marine phytoplankton, pp. 387-584. Academic Press, San Diego. 
Taylor FJR. 1976. Dinoflagellates from the International Indian Ocean Expedition. A report on material collected by the R. V. 'Anton Bruun' 1963-1964. Bibliotheca Botanica 132: 1234, pl. 1-46.

Utermöhl H. 1958. Zur Vervollkommung der quantitativen Phytoplankton Methodik. Mitteilungen der Internationale Vereinigung für Theoretische und Angewandte Limnologie 9: $1-38$.
Wood EJF. 1963. Dinoflagellates in the Australian region. II. Recent collections. Technical Papers of the Division of Fisheries Australia 14: 1-55.

Wood EJF. 1968. Dinoflagellates of the Caribbean Sea and adjacent areas, 142 pp. University of Miami Press, Coral Gables.

Received 14 April 2014 and accepted 7 July 2014

Associated Editor: Pilar Muñoz M. 